\title{
The moral economies of market societies: popular attitudes towards market competition, redistribution and reciprocity in comparative perspective
}

\author{
Sebastian Koos $\mathbb{D}^{1, *}$ and Patrick Sachweh ${ }^{2}$ \\ ${ }^{1}$ Department of Politics and Public Administration, University of Konstanz, Germany and \\ ${ }^{2}$ Department of Sociology, Goethe University Frankfurt, Frankfurt am Main, Germany \\ *Correspondence: sebastian.koos@uni-konstanz.de
}

\begin{abstract}
In a classical typology, Polanyi distinguishes three basic modes of economic integration: competitive market exchange, redistribution and reciprocity. While markets are dominant in modern capitalism, redistribution and reciprocity are-to varying extent-also part of its institutional architecture. Asking whether such institutional differences are mirrored in distinct 'moral economies', we investigate ordinary citizens' support for market competition, redistribution and reciprocity across 14 capitalist economies. Combining data from three comparative surveys, we analyze, first, the extent to which these principles are supported by citizens and whether they cluster into distinct 'moral economies'; second, whether these norms are anchored in formal institutional settings; and finally, how privileged and disadvantaged groups differ in their support. While support for market competition is strong across countries, it is to varying degrees complemented by support for redistribution and reciprocity. We identify a competition-dominated, an embedded and a strongly embedded moral economy. The interplay of formal institutions and people's socialstructural position partly explains differences in popular support.
\end{abstract}

Key words: redistribution, competition, family, capitalist systems, welfare state, moral norms

JEL classification: P16 political economy; Z13 Economic Sociology; D63 Equity, Justice, Inequality, and Other Normative Criteria and Measurement

\section{Introduction}

Markets are the dominant mechanism of economic organization in modern capitalist democracies (Swedberg, 2003; Aspers, 2009, p. 263; Beckert, 2009). Although some observers 
expected market principles to become discredited in the wake of the Global Financial and Economic Crisis (Heinze, 2010), and stricter regulations were (in some cases) imposed to restrain market activity, markets remain an essential element of modern capitalist economies. In fact, to some extent markets nowadays not only appear as the dominant mode of economic organization but also as a universal form of social organization more generally, as processes of 'marketization' and 'economization'-i.e. the expansion of market principles, market mechanisms and market ideology into non-economic social spheres-indicate (Slater and Tonkiss, 2001; Djelic, 2006; Crouch, 2009).

Yet, while markets may be central to modern economies, they are not their only organizational principle. Karl Polanyi (1992 [1957]) identified two further principles of economic organization: reciprocity, based on symmetrical social relations, and redistribution, based on centralized hierarchy. While both principles characterize the organization of traditional 'embedded' economies (Polanyi, 1957 [1944], pp. 43-55), economic sociology maintains that they remain important in contemporary market economies as well, as actual societies always evince a mix of the three principles (Swedberg, 2003, p. 28; Dale, 2010, p. 117). In the capitalist societies of the OECD world, redistribution has been most visibly institutionalized in the policies of the modern welfare state (Marshall, 1950; Esping-Andersen, 1990), whereas reciprocity manifests itself most notably in the various practices of family support (Albertini and Kohli, 2013). Importantly, the relative significance of these plural modes of economic integration differs considerably between countries, with different institutional configurations of these principles forming distinct 'varieties' (Hall and Soskice, 2001) or 'worlds' (Esping-Andersen, 1990) of capitalism.

We argue that such different institutional configurations, however, not only consist of formal 'rules of the game' (North, 1990) but also embody informal rules and taken-forgranted social norms about the proper role of various principles of economic organization. Such informal rules and norms are important because formal institutions are only stable and function effectively if they are supported by corresponding normative orientations on the part of citizens (Almond and Verba, 1989; North, 1990). Therefore, we examine whether popular attitudes towards the market, redistribution and reciprocity parallel the relative importance of these principles within the institutional architecture of capitalist societies in the OECD world. While extant research has assessed the relation between welfare state institutions and citizens' attitudes towards redistribution, (e.g. Mau, 2003; van Oorschot et al., 2008; Svallfors, 2010; Vrooman, 2012), people's views on markets and family support are considerably less well researched. Although earlier studies have looked at popular views of the market during the Post-Communist transition (Mason, 1995; Kluegel et al., 1999; Mason and Kluegel, 2000), interest in market attitudes has revived only recently (Lindh, 2014, 2015). Studies on attitudes towards the family often focus on gender roles, children or division of care work etc., but less on the family as a source of social support (Bolzendahl and Myers, 2004; Poortman and Van der Lippe, 2009). Moreover, existing research mostly analyzes perceptions of a single institutional sphere, thus neglecting potential interrelations between people's views about the market, the welfare state and the family. As a result, we know relatively little about the broader socio-cultural embedding of the institutional architecture of capitalist societies (but see Levien and Paret, 2012).

Against this backdrop, we investigate ordinary citizens' support for three different forms of economic integration-market competition, redistribution and reciprocity-across a range of economically and institutionally diverse capitalist economies, paying particular 
attention to the co-variation of these attitudes across nations. Situating ourselves within an interdisciplinary literature on the 'moral economy' of modern societies (Thompson, 1971; Mau, 2005; Svallfors, 2006; Fourcade and Healy, 2007; Sachweh, 2012), we assume that economic institutions are embedded in a wider horizon of shared social norms and values, which are part of ordinary citizens' thinking. Thus, we are interested in whether the institutionally diverse forms of economic integration identified by Polanyi are mirrored in citizens' normative orientations. Specifically, we formulate three research questions: (1) To what extent do citizens support the principles of market competition, redistribution and reciprocity across different countries, and do patterns of popular support cluster into distinct varieties of 'moral economies'? (2) Is there a relationship between citizens' normative orientations on the one hand and the relative importance of the institutionalized forms of market competition, redistribution and reciprocity on the other? (3) Finally, to what extent do privileged and disadvantaged social groups differ in their support for the principles of market competition, redistribution and reciprocity, and how does this relate to their institutionalized importance? These questions address the popular legitimacy of economic practices that is a crucial normative-cultural precondition of modern market economies.

Our article proceeds as follows. First, we elaborate Polanyi's three different modes of economic integration and how they are part of the institutional architecture of contemporary market economies (Section 2). Thereafter, we outline our 'moral economy'-perspective and formulate hypotheses on the relation between the different institutional modes of economic integration and citizens' normative orientations (Section 3). Section 4 describes the data and methods used, and Section 5 presents the results. In the conclusion, we discuss our findings against the backdrop of expectations from classical sociological theory about the normative underpinnings of modern capitalism.

\section{Plural modes of economic integration}

\subsection{Modes of economic integration: Reciprocity, redistribution and market exchange}

Polanyi (1992 [1957]) argued against a purely formal theoretical perspective which conceived of economic action solely as a rational choice under conditions of scarcity, thereby restricting the tool kit of economic analysis to the institutional conditions of a market system. Instead, he advocated a substantive understanding of the economy as an 'instituted process of interaction between man and his environment, which results in a continuous supply of want satisfying material means' (Polanyi, 1992 [1957], p. 33, emphasis added). Thus, economic life consists of a set of regular, ordered and interdependent practices for the production and distribution of goods and services. These practices are integrated and stabilized, and the economy thus 'instituted', through historically specific patterns of interaction and social relations-i.e. mechanisms of economic integration-which provide coherence to economic activities and integrate them into the larger society (cf. Dale, 2010, pp. 114-115).

The three basic 'forms of economic integration' Polanyi identifies are reciprocity, redistribution and market exchange. ${ }^{1}$ Reciprocity refers to the movement of goods and services between symmetrical groups; redistribution denotes a mode of economic organization in

1 In The Great Transformation, Polanyi adds house-holding as a fourth mode of economic integration (Polanyi, 1957 [1944]). 
which goods and services move towards a center and are (re)distributed by it; and exchange refers to the movement of goods and services between different actors under a competitive market system. Importantly, these different principles of organizing economic activity integrate the economy only in the presence of specific institutional structures surrounding and supporting them. Reciprocity assumes symmetrical social groups-e.g. systems of kinship in savage societies-to fulfill its integrative function, while redistribution presupposes the existence of an allocating center that (re)distributes goods and services-e.g. the state in socialist societies. Exchange, finally, will integrate the economy only in the presence of a system of price-making competitive markets (Polanyi, 1992 [1957], p. 35). Thus, the integrative effect of reciprocal behavior, redistribution and market exchange is conditional upon the 'presence of definite institutional arrangements, such as symmetrical organizations, central points, and market systems, respectively' (Polanyi, 1992 [1957], p. 35). These institutional arrangements are not mere aggregations of the respective individual behavior but represent a reality in their own right.

\subsection{Plural modes of economic integration-past and present}

Although different forms of economic integration may coexist on different levels or in different sectors of the economy, their significance also varies across time and countries. While Polanyi did not imply a progression of 'stages of development', he paid attention to the specific patterns by which societies at various historical time-points coordinate their economic activities and vest them with 'unity and stability' (Polanyi, 1992 [1957], p. 34). Whereas reciprocity via ties of kinship and fealty formed the dominant mode of economic integration in savage and feudal societies, redistribution through a center organized economic activity in tribal societies, in the ancient Kingdom of Egypt, or in state socialism (Polanyi, 1957 [1944], pp. 49-52).

In modern capitalist societies, market exchange has become the prevailing form of exchanging land, food and labor (Polanyi, 1992 [1957], pp. 37-39). With market dominance, however, the inherent instability of the market system becomes apparent. Analyzing the transformation of 18th-century England into an economic system centered on selfregulating markets, Polanyi (1957 [1944]) reconstructs how the commodification of land, labor and money gradually disembeds the market from its surrounding social relations, thereby subordinating the very substance of society itself to its laws (Polanyi, 1957 [1944], p. 71). He warns that '[a] market economy can exist only in a market society' (Polanyi, 1957 [1944], p. 71, emphasis added), which 'means no less than the running of society as an adjunct to the market. Instead of economy being embedded in social relations, social relations are embedded in the economic system' (Polanyi, 1957 [1944], p. 57). In reaction to the threats self-regulating markets pose for societal integration, counter-movements emerge that seek to re-embed disembedded markets in structures and institutions of social protection (Block, 2001, p. xxv). Thus, the evolution of the market system is described as a 'double movement' - a process in which 'the extension of the market organization in respect to genuine commodities was accompanied by its restriction in respect to fictitious ones' (Polanyi, 1957 [1944], p. 76).

In increasingly complex modern societies characterized by division of labor and functional differentiation, the re-embedding of markets cannot-as in traditional 'embedded economies'-occur solely on the small-scale level of individual interactions and personal life-worlds. As modernization processes unfold, the institutional structures of traditional 
societies, such as strong ties of kinship or a centrist organization of society, gradually lose their importance. Hence, formalized institutional arrangements come into being which institute reciprocity and redistribution as alternative principles of economic integration, thereby complementing, containing and/or correcting the market exchange of goods and services (cf. Beckert, 2012). As Swedberg notes, '[i]n each economy, [...], there is usually a mix of these three forms and their corresponding institutions: the family, the state, and the market' (Swedberg, 2003, p. 28).

Along this line, we focus on welfare state policies and family support as contemporary institutionalizations of the principles of redistribution and reciprocity, respectively. While these principles clearly do not organize the entire economy in modern societies, where markets play a key role, they still remain important for economic life-e.g. by stabilizing income flows, by enabling employment, or by providing goods or services where markets fail to deliver. Thus, they are part of the institutional architecture of contemporary market economies, and we now outline briefly how they contribute to the functioning of modern market economies. Because this institutional architecture differs across nations (Esping-Andersen, 1990; Hall and Soskice, 2001), we also summarize how countries vary in the emphasis they give to redistribution and reciprocity.

The policies of the welfare state (Marshall, 1950; Wilensky, 1975; Flora et al., 1977) most visibly institutionalize the principle of redistribution. ${ }^{2}$ Welfare state redistribution may occur 'vertically', i.e. between rich and poor people (via taxation and the provision of minimum income support), or 'horizontally', i.e. between different phases or events across one's life-course such as sickness, unemployment or old age (via social insurance or basic provision) (Barr, 2001). Redistributive policies can be regarded as contributing to the economic integration of society in so far as they enable participation in economic life in the face of various social risks, e.g. by providing people with low or no income with the financial means for consumption, or through making available public services (e.g. childcare) that facilitate labor force participation. In this sense, welfare state institutions complement or even enable economic action (i.e. consumption, employment), although this is certainly not their exclusive purpose and they are often said to hinder economic dynamics (Huber and Stephens, 2005). Moreover, welfare state policies also correct market outcomes, e.g. via the redistribution of income through taxation and the levying of social insurance contributions, or regulate market processes, as in the case of labor markets (Palme, 2006).

While there are several ways of assessing welfare state effort, we look at the difference in income inequality before and after government redistribution as an indicator of formalized redistribution (Bradley et al., 2003). ${ }^{3}$ Typically, the highest degree of redistribution is found

2 Of course, redistribution is not the only-and probably not even the most important-function of the welfare state. Another key aspect is insurance against risk and the stabilization of income flows across the life-course (Flora et al., 1977; Barr, 2001). Moreover, in recent debates a perspective that views social policies as 'social investment' is advanced (Morel et al., 2012). From this view, social policy should not merely compensate disadvantages once they have occurred (e.g. unemployment) but help to prevent risks before they arise (e.g. by enabling employment), thereby also yielding collective pay-offs in the long run. Family policies that aim at a reconciliation of work and care responsibilities are a prominent example.

3 Alternatively, social expenditures (as share of a country's GDP) are widely used-but not uncontested-indicator of welfare effort (OECD 2012). More recently, advances were also made in updating Esping-Andersen's original decommodification indicator (Scruggs et al., 2014) and 
in the Scandinavian countries, which have developed large and encompassing welfare states, followed by the Continental Western European welfare states (Palier, 2010), while the welfare states in the Anglo-Saxon, Mediterranean and Eastern European countries are less redistributive (Korpi and Palme, 1998; Huber and Stephens, 2005; Cook, 2010).

Reciprocity manifests itself in diverse practices and settings, most notably support provided within families (Albertini and Kohli, 2013) and the various practices of donations and volunteering (Adloff and Mau, 2006). ${ }^{4}$ While its institutional 'place' is less formalized than that of redistribution, it is equally important in contributing to the economic integration of modern societies. The social and material support provided within families delivers services or goods where the market and/or the state fail to provide them and can be a significant source of socio-economic stability (Newman, 2012; Albertini and Kohli, 2013). There are many instances in which family support is relevant to economic life, such as the balancing of work and family (Leitner, 2003), in the face of critical life-events such as unemployment (Newman, 2012), or in social reproduction via inheritance (Beckert, 2007; Szydlik, 2011). Hence, modern forms of informal reciprocity can complement, and at times even correct (or counter-act), market-based exchange. ${ }^{5}$

Yet, the importance of the family for absorbing social risks, and for welfare provision more generally, differs markedly across nations (Esping-Andersen, 1999; Leitner, 2003). It is typically lowest in the Scandinavian welfare states, where encompassing social safety nets and public services minimize dependence on the family, and somewhat greater in the Continental European and Anglo-Saxon countries, where family autonomy is upheld to a greater extent. A high degree of dependence on the family can be seen in the familialist Mediterranean nations and in Eastern Europe, where welfare states are least generous and encompassing (Esping-Andersen, 1999; Daly, 2010). As there is no aggregate indicator, which would allow for a direct operationalization of (instances of) family support for our country sample, we rely on the share of public spending for long-term care as an indirect measure (OECD, 2005). While this is no perfect indicator, studies show that in countries with little institutionalized provision of social and health services, such as Southern Europe, elderly parents are more likely to receive physical care from their children than in countries with encompassing social service provision (Brandt et al., 2009). Yet, this does not mean that family support is entirely 'crowded out' in Northern European countries, as children there are more likely to provide help with housekeeping (Brandt et al., 2009). ${ }^{6}$ Overall,

extending it beyond Western nations (Kuitto, 2016), but for our period of investigation there are still considerable data limitations.

4 Besides, the 'third sector' is an important provider of welfare and social support in many societies. Located between the state and the market, it encompasses a variety of actions, such as volunteering or civic engagement, which can be interpreted as a form of (generalized) reciprocity (Adloff and Mau, 2006; Koos, 2012).

5 Furthermore, while behavioral economics points out how reciprocity facilitates economic cooperation and exchange in market contexts (Fehr and Schmidt, 2006), it naturalizes reciprocity as an innate human tendency (Streeck, 2010, p. 391), thus ignoring its dependence on socio-structural and institutional contexts highlighted by Polanyi (1992 [1957]) and others (Sahlins, 1972).

6 Similarly, Albertini and Kohli (2013) also show that the types of support vary cross-nationally. In Southern Europe, parents support their children primarily through prolonged co-residence or by taking them back into the parental home in situations of economic distress, while in Continental European or Scandinavian countries, parents support their children through material transfers and 
however, the total amount of social support among family members can assumed to be greater in familial welfare states.

Finally, although markets form the core of capitalist economies, they are rarely totally free. On the one hand, they depend on external conditions, like property rights and contract law (Durkheim, 1893; Williamson, 1981). On the other hand, markets are often coordinated or governed by the state or private interest governments (Streeck and Schmitter, 1985) to avoid negative externalities, for instance exploitation of labor, environmental pollution or monopolies. Thus, a variety of market economies exists which differ strongly in the primacy given to market competition as a mode of economic coordination (Hollingsworth et al., 1994; Whitley, 1999; Hall and Soskice, 2001; Amable, 2003). While competitive markets assume a dominant role in the Anglo-Saxon economies, the coordinated or state-led market economies of Continental Europe place more emphasis on strategic or planned ways of coordination (Hall and Soskice 2001).

Importantly, although we have outlined how distinct societal spheres institutionalize the principles of competitive market exchange, redistribution and reciprocity, this is to some extent an analytical separation. In the real world, the boundaries between these principles may sometimes be blurred. For instance, research has documented reciprocal behavior in market exchange, as for instance evidenced in rent-sharing (Hildreth and Oswald, 1997; Rotemberg, 2006). Similarly, some argue that the welfare state cannot only be understood in terms of redistribution, but also reciprocity (e.g. Mau 2003). ${ }^{7}$ Furthermore, recent reforms have-to varying extent-introduced market principles in welfare provision, e.g. through the establishment of so-called 'welfare markets' (Gingrich, 2011). In sum, while it is plausible to assume that the principles of competitive market exchange, redistribution and reciprocity are the core notions underlying action in markets, welfare states and families, it does not preclude that we may observe a mixture of principles at work in these different spheres.

\section{A moral economy of market society?}

Insofar as they limit the scope of the market by functioning as alternative providers of goods, services or material resources, welfare state policies and families can be seen to contribute to the 'embedding' of modern market economies in non-economic social structures. By providing goods and resources according to principles other than supply and demand, they contribute to the constitution of what may be called a moral economy (Mau, 2005; Sayer, 2007), i.e. an institutional and normative embedding of modern market societies in collectively shared non-economic values and principles of social organization.

The moral economy approach views this normative embeddedness as emerging out of a historical co-evolution of society's institutional arrangements on the one hand and citizens'

partly through co-residence in certain critical life-events (divorce, widowhood) (Albertini and Kohli, 2013, pp. 836-837).

7 Yet, such an interpretation is incongruent with a Polanyian notion of reciprocity, which assumes non-hierarchical (or 'symmetrical') relations between the giving and receiving parties. In contrast, the provision of welfare state benefits and services, as well as contributing to their financing, is legally enforceable in hierarchical relations between states and citizens, characterized by power asymmetries, which is (typically) not implied in a Polanyian understanding of reciprocity (Polanyi, 1992 [1957]). 
normative orientations on the other (Thompson, 1971; Mau, 2005; Sachweh, 2012). Unlike in the new institutional economics (North, 1990), institutions are understood not only as formal 'rules of the game' but also seen to embody specific guiding principles, or Leitideen, thus representing conceptions of a legitimate social order (Weber, 1980 [1922]; Lepsius, 1995). This implies that, on the one hand, institutions depend on the popular support of citizens, but that on the other hand, they also possess a norm-generating capacity, which can shape citizens' orientations through processes of normative policy feedback (Rothstein, 1998; Svallfors, 2006, p. 2). Thus, an 'elective affinity' between institutionalized norms and citizens orientations is likely to exist.

To be sure, a correspondence between institutions and people's opinions is not established in a straightforward process. Neither do people adapt to institutional arrangements unquestioningly, nor do institutions simply follow from people's preferences. ${ }^{8}$ Institutions and the normative ideals they embody define how rights and responsibilities are distributed among members of a political community. Therefore, they are likely to be contested between powerful and subordinate social groups, with different sides trying to establish specific-and possibly competing - conceptions of a 'legitimate' social order (Fourcade and Healy, 2007, p. 305; Beckert, 2009). The process of instituting economic practices may therefore be accompanied by conflicts and social struggles since it 'includes the settling of these 'constitutive' normative issues of rights and responsibilities, whether by argument or power' (Sayer 2007, p. 364). Accordingly, the classical analyses by Thompson (1971) or Moore (1978) have highlighted how institutional changes-when seen as representing an illegitimate break with traditional social order-have often triggered moral outrage and feelings of injustice, thereby uncovering the tacit assumptions that constitute a 'moral economy'. However, while social change may evoke public controversies about these taken-for-granted assumptions, such conflicts are not permanent. Eventually, as Sayer (2007, p. 264) notes, '[w]hat was once a matter of legitimacy becomes simply a matter of "how things are" [...]', and in the long run, some degree of agreement between different groups over the prevailing institutional arrangement is likely to emerge. Thus, over time the institutional order is based not only on pragmatic legitimacy (rooted in self-interest) and moral legitimacy (rooted in normative consent), but also assumes a certain 'cognitive legitimacy', i.e. a 'taken-for-grantedness' (Suchman, 1995) which reveals itself in times of radical change or crises (Thompson 1971). Yet, since under democratic conditions no institutional order can be upheld by sheer force (or habit), from time to time the prevailing institutional arrangement may be questioned or challenged, thus creating a pressure for renewed legitimation (or institutional change) (Streeck and Thelen, 2005). In sum, while the 'moral economy' perspective assumes that ultimately some degree of correspondence between institutionalized norms and popular opinion emerges, it does not assume that this happens without contestation.

Along these lines, we expect that citizens' support for market competition, redistribution and reciprocity is related to their institutionalized significance in the respective countries.

8 We assume that there is a mutual influence of institutions and preferences. Due to the crosssectional nature of our data, it is not possible to say anything about the temporal ordering of the processes. Yet, while formal institutions have widely changed over the last decades, crucial institutional differences in the political economies remain (e.g. between the residual Anglo-Saxon welfare states versus still comparatively extensive Scandinavian welfare states). Therefore, in line with the moral economy literature we focus on the correspondence of institutions and moral economy. 
Specifically, we hypothesize that (a) support for market competition should be high in countries where markets are less regulated and market principles more strongly institutionalized, while (b) support for redistribution should be greater in countries with higher levels of stateadministered redistribution, and (c) support for the principle of reciprocity should by greater in countries where care for the old is not strongly supported by the state, but instead carried out by families.

As we have argued, the institutional and normative architecture of capitalism is likely to be contested between different social groups. Referring specifically to Polanyi's modes of economic integration, Szelényi and Kostello (1992) posit that the dominant mode of integration-i.e. markets in capitalist societies-is also the main source of social inequality, while compensatory modes-i.e., redistribution and reciprocity—may mitigate inequality. ${ }^{9}$ On the one hand, welfare states and families supply those with limited or no market access with goods and services they would not have otherwise. On the other hand, especially the 'beneficiaries' of market exchange have to contribute parts of their income to the welfare state (through taxes or social insurance contributions) or share their income with dependent family members, if welfare states are residual. Therefore, we expect that groups benefiting to different degrees from the market, the welfare state, and their family will differ in their support for these principles. More specifically, individuals in higher socio-economic positions, who are more likely to gain from competitive markets, should be more supportive of free market competition, and less supportive of both redistribution and reciprocity. Conversely, individuals in lower socio-economic positions, who might be more dependent on statesponsored benefits or family support, should be more supportive of redistribution and reciprocity, and less supportive of market competition. While research on attitudes towards the market is scarce, earlier research carried out within the International Social Justice Project (ISJP) has shown that support for principles of 'market justice' is greater among those in higher socio-economic positions (Kluegel et al. 1999, p. 264; Mason 1995). Conversely, a large literature on redistributive preferences shows that support for redistribution is clearly structured along socio-economic lines, with those in lower socio-economic positions showing greater support for redistribution than those in advantaged socio-economic positions (see, for instance: Mau, 2003; Svallfors, 2006; Schmidt-Catran, 2016). Similarly, Levien and Paret's (2012) study on the resistance to neoliberalism finds stronger 'pro-embeddedness sentiments' among people with low income.

Finally, countries differ with regard to the institutionalized importance of markets, the welfare state and the family (Esping-Andersen, 1990; Hall and Soskice, 2001). This implies that the extent to which disadvantaged groups benefit from market-embedding institutions is greater in countries where the role of markets is less pronounced, where the generosity of welfare states is higher, and/or where the family assumes a greater role; correspondingly, greater contributions are demanded from privileged groups in such nations. Thus, we further assume that differences in popular support for the three modes of integration between privileged and disadvantaged groups should be greater when (a) markets are more strictly regulated, (b) when welfare states are more generous and (c) when the role of the family is greater.

9 Of course, conservative welfare states also maintain status hierarchies emerging in the labor market, and upper-class families often successfully reproduce their advantages over generations. 


\section{Data, variables and methods}

\subsection{Data}

To investigate the moral economy of market societies and evaluate our hypotheses regarding its institutional embeddedness and attitudinal cleavages between privileged and disadvantaged groups, we use survey data on people's normative preferences for the three forms of economic integration. For a lack of integrated survey data on these aspects, we combine information of three large-scale comparative surveys for 14 countries. The data sets are the 1999/2000 wave of the World Value Study, the 1999 ISSP on 'Social Inequality' and the 2001 ISSP on 'Social Networks'. All surveys have been compiled between 1999 and 2001, minimizing time-induced variations in the evaluation of market exchange, redistribution and reciprocity as means of economic integration. Unfortunately, due to the different data sources and the alternating ISSP modules, an analysis of developments over time is not feasible. Our sample includes the following OECD-countries: Austria-AT, Australia-AUS, CanadaCA, Czech Republic-CZ, Germany-DE, Spain-ES, France-FR, Great Britain-GB, HungaryHU, Japan-JP, Norway-NO, New Zealand-NZ, Poland-PL, United States of America-US.

\subsection{Variables}

Since we rely on secondary survey data, the operationalization of popular support for market exchange, redistribution and reciprocity is not without caveats. While support for redistribution and reciprocity can be measured with relatively straightforward questions, the operationalization of support for market principles is more difficult.

To measure support for market principles, we focus on a central feature of markets: competition. Following Aspers (2009, pp. 7-8), one can argue that competition between economic actors is the central characteristic distinguishing market exchange from processes of (dyadic) trade. Support for market competition is operationalized using a question of the World Value Study 1999/2000, which asked respondents to provide their opinion on a scale (1-10) with the following opposing statements as the poles: 'Competition is good. It stimulates people to work hard and develop new ideas' (1). 'Competition is harmful. It brings out the worst in people' (10). We reverse the scale and divide it by two to arrive at a scale comparable with the other two dependent variables, so 5 represents a positive and 1 a negative evaluation of competition. Aware of the fact that competition can also occur outside the economy, we correlated this item with a question asking whether respondents endorse private ownership of firms in contrast to state ownership, and both items are positively correlated across countries (Pearson's $r=0.6$; $P<0.05)$. Thus, although our operationalization may not be entirely optimal, the item refers to two central capitalist dispositions-'hard work' and innovativeness (cf. Weber 2002)—and is positively correlated with support of private firm ownership. We therefore conclude that it adequately reflects economic competition.

We operationalize support for redistribution with a well-established and widely used item taken from the ISSP 1999 asking whether 'the government should reduce differences in income between people with high incomes and those with low incomes'. Respondents could answer on a five point scale ranging from 'strongly agree' (1) to 'strongly disagree' (5) with a neutral mid-point 'neither agree nor disagree'. Again, the scale was reversed, so 5 represents a preference for government redistribution.

Finally, reciprocity here is understood and measured as 'generalized reciprocity' (Sahlins, 1972, p. 193) in which the giving of one party to another and its reciprocation are 
temporarily decoupled, as in the exchange between parents and children over the life course. To measure the evaluation of generalized reciprocity we make use of a question in the ISSP 2001. Respondents were asked whether they agree or disagree with the following statement: 'adult children have a duty to look after their elderly parents'. Answers were ranked on a five point scale ranging from 'strongly agree' (1) to 'strongly disagree' (5) with a neutral mid-point 'neither agree nor disagree'. Again, the scale was reversed, so 5 represents a preference for reciprocity. Also this operationalization is not without limitations, and a more general measure of support for reciprocity would have been preferable. Still, we think this item reflects a central manifestation of reciprocity in modern societies and therefore is well suited for our analysis.

To control for systematic individual differences in the evaluation of the three modes of economic integration, we include a set of socio-demographic variables. Complicated by differences in measurement across the three surveys, we confine our analysis to a basic set of variables, which we recoded in a way to ensure comparability. Beside gender and age (in years), with an additional squared age term to account for a potential curvilinear relationship, we include three measures of respondents' socio-economic position: education, employment status and income. Education is measured by the highest education level a respondent has achieved and is coded into three categories: primary education or less, secondary and tertiary education (ISCED). Next, employment status is measured with a dummy variable indicating whether a respondent is unemployed or not. Finally, we include household income as a measure of material well-being and recode income into four groups: the 'relatively poor', defined as the $20 \%$ of respondents with the lowest income in a country, the 'relatively affluent', defined as those $20 \%$ with the highest income, a group of the remaining $60 \%$ with middle incomes, and a missing income category. ${ }^{10}$

To analyze the institutional embeddedness of the moral economy, a set of macro variables is gathered on the country level (referring to the year 1999, if not explicitly indicated) and merged with the three individual level data sets. The degree of market regulation is measured using the Economic Freedom of the World index (Gwartney et al., 2011) for the year 1995. Since the overall index is quite encompassing, for the purpose of this article we focus on one dimension measuring the regulation of credit, labor and business in a country (area 5). The index ranges from strongly regulated (0) to high economic freedom (10), but we reversed the scale so higher scores reflect stronger market regulation. While a Polanyian perspective would emphasize that regulation can also enable the functioning of markets and that 'de-regulated' markets too require state regulation (Block and Somers, 2014, p. 20), other current research also uses the above index as a measure of economic liberalization (Kwon, 2016). As an alternative measure we also make use of a coordination index based on the 'Varieties of Capitalism' literature (Hall and Gingerich, 2004; Schneider and Paunescu, 2012). Specifically, to overcome the limitations of Hall and Gingerich's (2004) coordination index (Witt and Jackson, 2016) and include the countries in our sample that were initially not covered, we use data on eight institutional measures for the year 1999 taken from Schneider and Paunescu (2012). After $z$-standardizing the measures we predict a factor score based on a principal factor analysis (Eigenvalue 4.7, explained variance $67 \%$ ),

10 With the terms 'relatively poor' and 'relatively affluent', we do not refer to the established thresholds for measuring poverty and wealth but rather use them as illustrative labels to facilitate the interpretation of our results. 
which we then use as a proxy for coordination (Witt and Jackson, 2016, p. 802). ${ }^{11}$ In addition, we utilize the OECD employment protection legislation (EPL) index (OECD, 2009) (cf. Table 2).

As a measure for institutionalization of redistribution, we calculated the percentage change between market and net household income inequality. ${ }^{12}$ Gini coefficients for preand post-government income inequality were taken from the Standardized World Income Inequality Database (SWIID) (Solt, 2016). This measure reflects the extent of governmentinduced reduction in income inequality, and thus accords with the attitudinal measure of redistribution. Moreover, this variable is not plagued by missing data for the Eastern European countries for the time-period studied, a problem that concerns all other available institutional measures (e.g. welfare generosity, decommodification), except social expenditures. Therefore, as an alternative measure we use social expenditures (as percent of GDP) (OECD, 2012). Moreover, despite the missing data for Eastern Europe we also checked our results against the welfare generosity index from the Comparative Welfare Entitlements (CWED) data (Scruggs et al., 2014), substituting the missing values for Hungary, Poland and the Czech Republic with generosity scores taken from Kuitto (2016) for the earliest available years (2005) as a robustness check. ${ }^{13}$ The results are reported in Table 2.

With respect to reciprocity, we focus on the family. Indicators on institutional manifestations of reciprocity are scarce. To date no encompassing comparative data is available on policies supporting family reciprocity [for an exception, see Leitner (2003) on family care arrangements in $9 \mathrm{EU}$ countries]. Therefore, we instead use public expenditures on longterm care (LTC) (as \% of GDP) referring to the year 2000 (OECD, 2005, p. 27) as an indicator of the extent to which the state assumes responsibility for elderly care, thereby relieving family members from reciprocity obligations which they otherwise would need to fulfill. ${ }^{14}$ As alternatives measures we use public spending on family benefits (as \% of GDP) and the average household size (natural $\log$ ) as a proxy of the importance assigned to family as a locus of exchange and support in a country. Data for both measures were taken from the OECD Family Database for the year 1999 (OECD, 2014). Both alternative measures have some problems; family benefits are strongly centered around child-care arrangements and

11 We followed the procedure described by Witt and Jackson (2016, p. 802). Our resulting factor score is strongly correlated to their coordination index for 11 overlapping countries in 1999 (Pearson's $r=0.89 ; P>0.01)$.

12 Using the absolute difference between disposable-income and market-income Gini coefficients (see Kenworthy and Pontusson, 2005, p. 455), rather than the percentage change, produced consistent results.

13 This operationalization is obviously problematic and the generosity scores for the Eastern European and the other countries in the sample are hardly comparable. In the Supplementary Appendix, we provide scatter plots of the three aggregated dependent variables with each of the respective macro-level independent variables (Figures A3 to A5). The correlation between the generosity score and support for redistribution is somewhat weak (Figures A4), yet the relationship becomes stronger if the Eastern European Countries are excluded (Figure A6).

14 More than $80 \%$ of the long-term care recipients are of old age (OECD, 2005, p. 25), therefore this variable seems to be well suited to measure institutionalized care for the old. The resulting country groups strongly overlap with Leitner's clusters of familialism and therefore this seems to be an acceptable proxy for institutionalized reciprocity. 
only partially reflect care for the old (as measured by our attitudinal item). The size of the household is a very general measure, partly reflecting economic development as indicated by its strong correlation with GDP. The results are reported in Table 2. Finally, we control for the level of economic development of a country using the natural log of GDP per capita in purchasing power parities (in international 2005 \$) (Worldbank, 2012) for the year 1999.

\subsection{Methods}

To investigate our research questions empirically, we use descriptive, explorative and multivariate statistical methods. First, we dichotomize the continuous dependent variables and calculate the share of respondents supporting the three forms of economic integration in each country. ${ }^{15}$ After reporting average country differences, we use a hierarchical cluster analysis (HCA) with Ward's linkage to analyze whether countries can be grouped into distinct clusters of 'moral economies'. This method allows identifying groups of cases which share similarities and differ from other cases by maximizing heterogeneity between clusters (Everitt et al., 2011). The analysis starts by assigning each country to one cluster. In consecutive steps, the countries are then joined together in clusters depending on shared similarities and differences until finally all countries join one large group. To assess the number of clusters that best fit the data, we first use a visual depiction of cluster solutions in a dendrogram. Moreover, we estimate the Duda/Hart JE(2)/JE(1) index which indicates the optimal cluster solution (Duda and Hart, 1973). As a robustness check we also used other clustering methods, like average and median linkage, which mostly provide consistent results (see Figures A1 and A2 in Supplementary Appendix).

Finally, we address the institutional embeddedness of and individual-level social structural influences on the moral economies by using hierarchical linear regression analysis, appropriate for modeling the multilevel structure of the data (Snijders and Bosker, 1999). The advantages of such models are that they correct for biases in parameter estimates and standard errors resulting from hierarchical data (individuals nested within countries) and allow for a separation of the variances between individual and contextual level (Guo and Zhao, 2000, pp. 444-445). In the analysis, both, individual-level and contextual-level variables are introduced simultaneously into random intercept regression models. These models allow to assess which variables at both levels are associated with the outcome and how much of the variation in the dependent variables between countries can be explained by individual characteristics (composition effects) and country specific factors. A context effect means that country characteristics, like market regulation, influence the mean outcomes of the dependent variables. Moreover, it allows including cross-level interactions, thus testing whether the effect of individual level coefficients (e.g. household income) is moderated by contextual level variables (e.g. market regulation).

As a robustness check, we re-estimated the micro-level models using country-fixed effects (Table A1 in Supplementary Appendix). Results remain consistent. Moreover, to test whether the limited number of countries creates a problem for the robustness of our findings we ran a set of additional analysis using a two-step procedure as suggested by Bryan and

15 We coded respondents as supporters of competition, redistribution, or reciprocity if they report a value of 4 or 5 on each scale, reflecting agreement with competition, redistribution and reciprocity, respectively. 
Jenkins (2016). ${ }^{16}$ The results reported in the Supplementary Appendix (Table A2) support the robustness of our findings.

\section{Results}

\subsection{Descriptive findings}

The descriptive findings depicted in Figure 1 present the different levels of normative support for the principles of market competition, redistribution and reciprocity, respectively, across the 14 countries analyzed here. Looking at the distributions of aggregate support for the three principles, considerable differences are evident (cf. Figure 1). In general, all types of principles receive rather similar levels of support across nations (market competition 64.7\%; redistribution $62.6 \%$; reciprocity $64.4 \%$ ). However, support for market competition varies less between countries $(\mathrm{SD}=9.4)$ than support for redistribution $(\mathrm{SD}=14.6)$ and reciprocity $(\mathrm{SD}=15.1)$.

Looking at the cross-national differences in citizens' support for market competition, the highest levels of support-encompassing 70 percent or more of the respondents—can be found in the United States, New Zealand, Australia, Austria, Norway and the Czech Republic. In contrast, the lowest levels of support, involving less than $55 \%$ of the respondents, characterize Spain and France. Medium levels of support for market competition encompassing 55-69\% of the respondents are found in Canada, Germany, Great Britain, Hungary, Japan and Poland. Thus, while some of the highest levels of support are found in the Anglo-Saxon liberal market economies, support for market competition is also fairly high in some Western and Eastern European countries.

With regard to redistribution, we find the highest levels of support involving $70 \%$ or more of the respondents in post-communist countries such as Poland, Hungary or the Czech Republic, but also Austria and Spain. Medium levels of support ranging between 55 and 69 percent of the respondents can be found in Germany, France, Great Britain and Norway, while less than $55 \%$ of the respondents support redistribution in the USA, Canada, Australia, New Zealand and Japan. Thus, support for redistribution is least pronounced in liberal market economies, and most supported in the post-communist nations.

Finally, high levels of popular support for reciprocity (70\% or more) are found in Spain, Poland, the Czech Republic, Hungary, France and the USA, while medium levels of support (between 55\% and 69\%) are found in Germany, Austria and Norway. Support for reciprocity is fairly low (less than 55\%) in Canada, Japan, New Zealand, Great Britain and Australia. With the exception of the USA, reciprocity is least supported in the Anglo-Saxon countries, while it is strongly supported in Eastern and Southern European countries.

These patterns suggest that there is some co-variation in citizens' normative support for market competition, redistribution and reciprocity across countries. Therefore, in Figure 2, we present the results of a hierarchical cluster analysis to detect whether there are distinct varieties of moral economies. The dendrogram shows how countries cluster together based on popular support for the three forms of economic integration. The JE(2)/JE(1) value and the pseudo $T$-squared value of the Duda-Hart index provide ambiguous results with regard to the optimal number of clusters, indicating that two to three clusters represent the best

16 The two-step procedure uses the coefficients of the country-fixed effects models (reported in Table A1) as dependent variables running simple OLS regression models. 


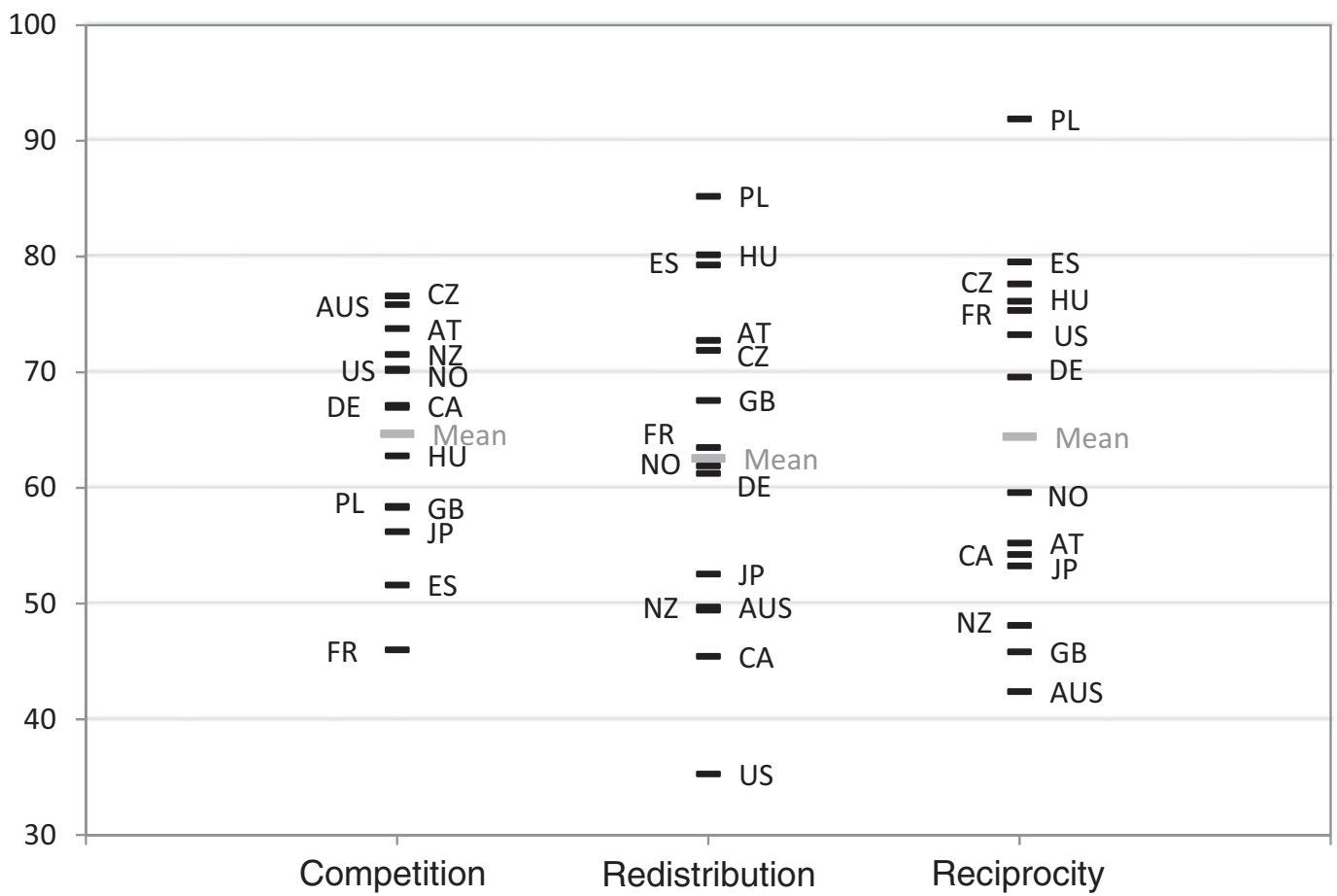

Figure 1. Average support for Competition, Redistribution and Reciprocity (in \%). Sources: WVS 99/00, ISSP 99, ISSP 2001, own calculations. Fourteen countries.

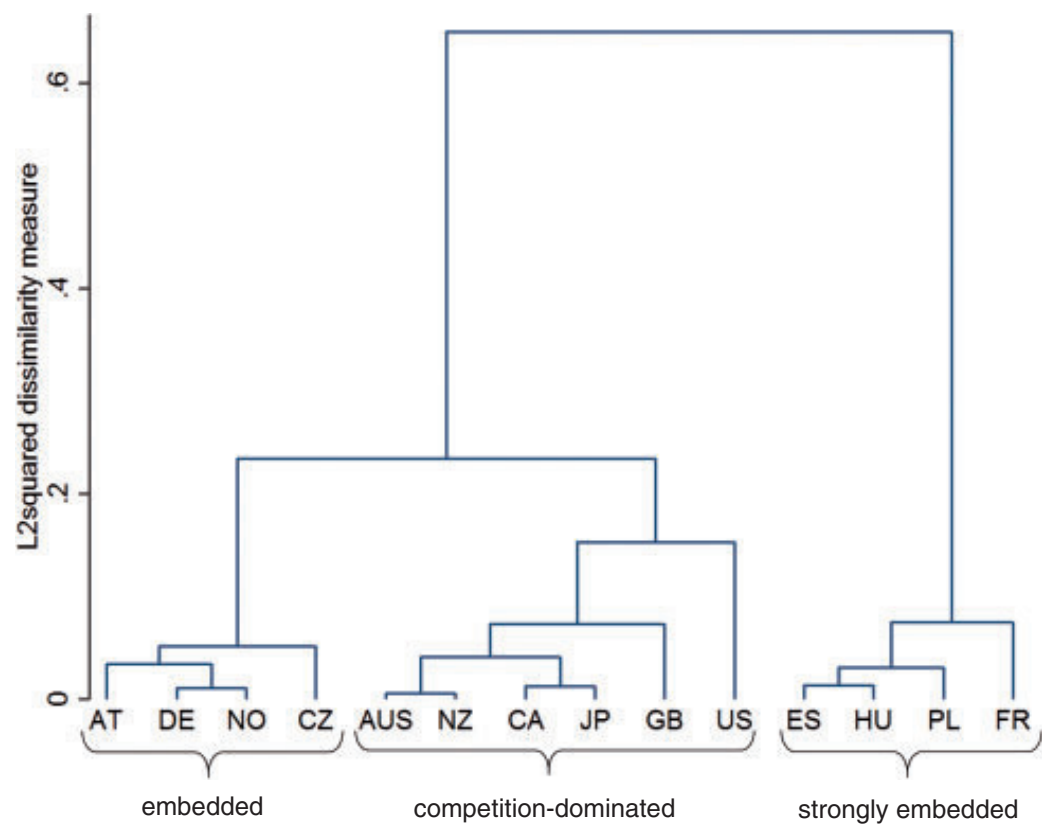

Figure 2. Dendrogram for moral economy cluster analysis.

Note: Hierarchical cluster analysis with Ward's linkage, based on mean support for competition, redistribution and reciprocity in 14 countries.

Sources: WVS 99/00, ISSP 99, ISSP 2001, own calculations. 
grouping of countries, while visual inspection suggests that at least three groups of countries can be distinguished. ${ }^{17}$

On the highest level of dissimilarity, two groups can be discerned: first, a large group of Continental European and Anglo-Saxon countries plus Japan, and second, a mixed group of Southern and Eastern European countries. This latter group of countries, comprising Spain, Poland, Hungary and France, is characterized by a below average support for competition and a high approval for both redistribution and reciprocity. Therefore, we term this cluster 'strongly embedded moral economies'. Within this cluster, the French respondents seem to be the most critical of market competition, but at the same time less supportive of both redistribution and reciprocity than people in the other countries of this cluster.

The former group, consisting of the Continental European countries, the Anglo-Saxon countries and Japan, can be subdivided into two sub-clusters. In the first subgroup, made up of Austria, the Czech Republic, Germany and Norway, the idea of competition is rather strongly supported, but at the same time we observe a medium to high approval for both redistribution and reciprocity. Therefore, we term this group 'embedded moral economies'. Within this group, people in the Czech Republic show a strong support for all three modes of economic integration, thus resembling the moral economy of the continental European countries, rather than that of the competition-adverse Eastern European countries. The Anglo-Saxon countries and Japan, as the second sub-cluster, represent the purest type of 'competition-dominated moral economies', with mostly strong support for competition (except in Japan and Great Britain) and the least support for both redistribution and reciprocity. In this cluster, especially the USA deviates from the other countries mainly due to its high value for reciprocity. The unique position of the USA when compared to all other countries illustrates the importance of assuming a more encompassing moral economy perspective on different modes of economic integration. While a strong support of competition and extremely low support of redistribution can be expected for the USA following extant research (Kluegel and Smith, 1986; Lipset, 1996; Svallfors, 2006), the high support for reciprocity we find complements existing studies by showing that reciprocity is a fundamental principle for embedding the market in the US context. Conversely, the UK, while showing low support of reciprocity and only moderate support of market competition, has an above average share of supporters of redistribution. Hence, people in the UK seem to share an understanding of social embedding with the Continental European countries, and therefore its moral economy is slightly distinct from the other Anglo-Saxon countries.

In sum, market competition is strongly supported by the citizens of the countries in our sample, but it is to varying degrees embedded in popular support for redistribution and reciprocity as well. Next, we use multivariate regression models to analyze whether these normative preferences correspond to a set of respective institutions.

\subsection{Multivariate findings}

Having described the moral economies of market societies, we now proceed to evaluate the formal institutional anchoring of the normative support for the three modes of integration. Constrained by the three distinct data sets for our dependent variables, we analyze each form of integration separately. We expect that support for the different modes of integration is conditional upon the specific and historically evolved institutional arrangements of the

17 Such ambiguous cluster solutions are not uncommon for HCAs (Everitt et al., 2011). 
Table 1. Multi-level regression results

\begin{tabular}{|c|c|c|c|}
\hline Variable & $\begin{array}{c}\text { Model } 1 \\
\text { Competition }\end{array}$ & $\begin{array}{c}\text { Model } 2 \\
\text { Redistribution }\end{array}$ & $\begin{array}{c}\text { Model } 3 \\
\text { Reciprocity }\end{array}$ \\
\hline \multicolumn{4}{|l|}{ Individual effects } \\
\hline Constant & $3.498 * * *$ & $3.712 * * *$ & $3.875 * *$ \\
\hline Female, Ref.: male & $-0.131 * *$ & $0.176 * *$ & $-0.118 * \cdots *$ \\
\hline Age & $0.003 * * *$ & 0.001 & $-0.027^{* * *}$ \\
\hline $\mathrm{Age}^{2}$ & & & $0.000 * * *$ \\
\hline \multicolumn{4}{|c|}{ Education level, Ref.: primary education } \\
\hline Secondary education & $0.098 * * *$ & $-0.187 * *$ & $-0.077^{* * *}$ \\
\hline Tertiary education & $0.146 * * *$ & $-0.406 * * *$ & $0.0603 * *$ \\
\hline \multicolumn{4}{|c|}{ HH Income, Ref.: middle income } \\
\hline Relative poverty & $-0.0755^{* * *}$ & $0.139 * * *$ & $0.0663 * *$ \\
\hline Relative affluence & $0.110 * * *$ & $-0.328 * *$ & 0.003 \\
\hline missing value & $-0.046^{+}$ & $-0.138 * *$ & 0.027 \\
\hline Unemployed & $-0.203 * * *$ & $0.193 * * *$ & -0.002 \\
\hline \multicolumn{4}{|l|}{ Contextual effects } \\
\hline Market regulation & 0.045 & & \\
\hline Inequality reduction & & $0.018^{*}$ & \\
\hline Long term care & & & $-0.473 * *$ \\
\hline Variance Random Intercept & 0.043 & 0.076 & 0.090 \\
\hline ICC & $3.2 \%$ & $5.8 \%$ & $8.1 \%$ \\
\hline $\mathrm{N}$ & 20289 & 16699 & 16602 \\
\hline BIC & 62947.2 & 51093.3 & 47798.8 \\
\hline Log-Likelihood & -31414.1 & -25488.3 & -23836.3 \\
\hline
\end{tabular}

Note: Unstandardized regression coefficients; significance levels:

$* * P>0.001, * * P>0.01, * P>0.05,{ }^{+} P>0.10$.

Sources: WVS 99/00, ISSP 99, ISSP 2001, own calculations. 14 countries.

societies analyzed. For instance, a political economy which strongly regulates markets and grants far-reaching social rights is most likely to be accompanied and legitimated by strong normative support for redistribution and rejection of competition by its citizens. Table 1 depicts three hierarchical linear regression models of the support for competition (Model 1), redistribution (Model 2) and reciprocity (Model 3). We start the analysis by estimating the intra-class correlation (ICC) for each dependent variable using empty models (without any independent variables, not shown here). The ICC indicates the share of variance roughly attributable to country differences. We find a significant share of variance on the macrolevel for each dependent variable, which is however only of modest size with respect to support for competition $(3.5 \%)$, and higher with regard to support for redistribution $(9.7 \%)$ and reciprocity $(11.9 \%)$. Following our theoretical discussion, we first present the institutional effects in Tables 1 and 2. Thereafter, we turn to the individual-level variables and discuss attitudinal cleavages between privileged and disadvantaged respondents and whether these are shaped by institutional conditions.

Table 1 shows how the three institutional indicators for market competition, redistribution and reciprocity affect popular support for these principles, controlling for individual- 


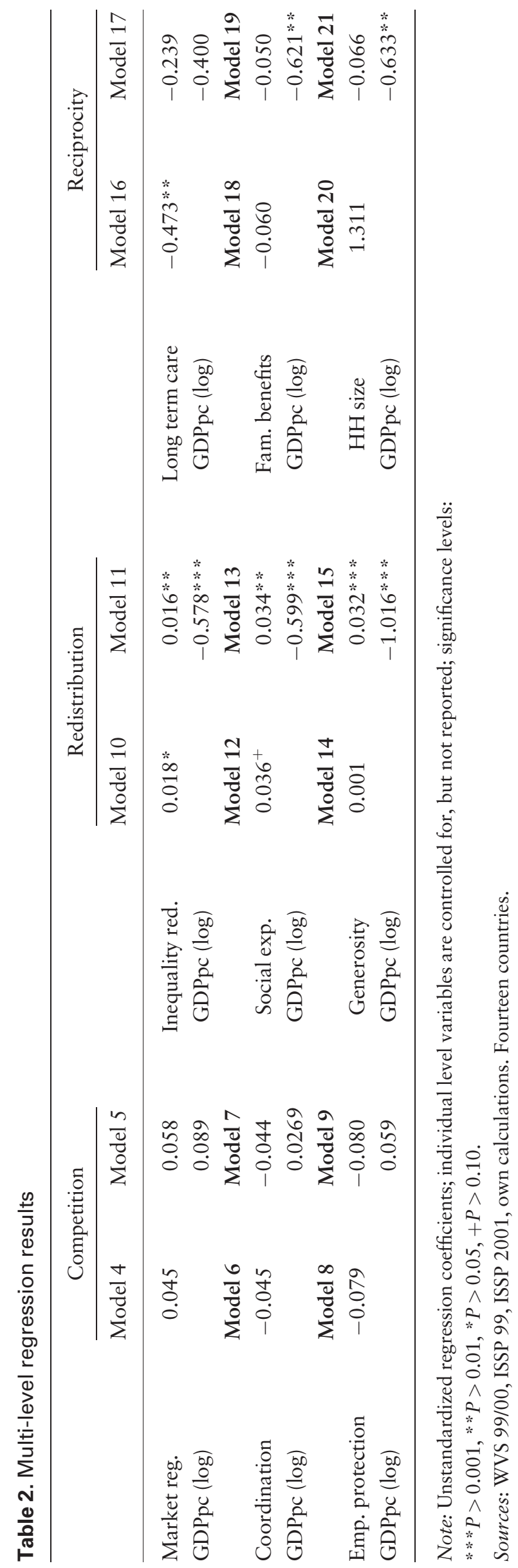


level correlates. In the first model (Model 1), we find that market regulation is not significantly associated with popular support for competition. In contrast, a higher reduction of social inequality-and hence more developed welfare states-positively affects support for redistribution (Model 2). Thus, more extensive welfare states are complemented by higher levels of support for redistribution. Likewise, for the institutional embeddedness of reciprocity (Model 3), we find a statistically significant negative effect of public expenditure for long-term care on support for reciprocity. Hence, as expected, support for reciprocity is lower where care for the old is institutionalized to a greater extent. The independent variables reduce the macro-level variance only to a limited degree for the support for competition, but by almost half for the support for redistribution $(5.2 \%)$, and by one third for reciprocity $(8.1 \%)$. In sum, the importance of specific institutions for the normative support of the three modes of economic integration can so far only be confirmed for market-embedding institutions.

In order to check whether these results are robust against alternative operationalizations of the institutional indicators, Table 2 depicts the models for the three attitudinal measures and all specific institutional measures, including the alternative indicators discussed in Section 4.2. ${ }^{18}$ We start by solely introducing the respective institutional measure in a first step, adding economic development (log GDP per capita) as a control in a second step. The individual-level correlates are always included, but not reported. Due to the restricted number of countries, we limited the analyses to two macro level variables at a time. While Model 4 is identical to model 1, in Model 5 we added GDP per capita $(\log )$. Neither market regulation nor the level of economic development have a statistically significant effect on the support for redistribution. This finding is supported when using alternative institutional measures for regulation, i.e. the coordination index (Models 6 and 7) and employment protection (Models 8 and 9) and when controlling for GDP per capita. Thus, support for market competition seems to be largely independent of the market regulating institutions.

Regarding support of redistribution, we observe that institutionally induced reduction of inequality has a statistically significant positive effect even when controlling for the level of economic development (Model 11), which has a significant negative effect. Interestingly, the alternative institutional measures of redistribution, social expenditures (Model 12) and welfare generosity (Model 13), only show a robust statistically significant effect if GDP per capita $(\log )$ is controlled for (Models 13 and 15). Hence, while people in more affluent countries are less supportive of redistribution, respondents in countries with higher levels of institutionalized redistribution also show greater normative support for redistribution.

Finally, the institutional measure for reciprocity (expenditure for long-term care) loses its statistical significance when controlling for economic development (Model 17). Likewise, GDP per capita $(\log )$ itself has no statistically significant effect. Yet, both variables are strongly correlated (Pearson's $r=0.81 ; P<0.05$ ). Furthermore, the alternative institutional measures for reciprocity (family benefits and household size) also have no statistically significant effect, neither when introducing them on their own (Models 18 and 20) nor when

18 In addition, we estimated models using welfare regime dummies. Since these clusters strongly overlap with the varieties of capitalism clusters, we did not run separate (VoC) models. Results, which are reported in the Supplementary Appendix (Table A3), support the findings of the institutional measures reported here. 
controlling for GDP per capita (log). However, in Models 18 and 20, economic development has a statistically significant negative effect on support for reciprocity. Thus, differences in support for reciprocity seem to be largely driven by economic development, whereby people in economically more developed countries have a lower likelihood to support reciprocity. The robustness check using a two-step procedure (see Supplementary Appendix) provides support for the results of all multilevel models reported above.

Finally, looking at the individual-level variables (Table 1), we find that being relatively affluent, i.e. belonging to the upper $20 \%$ of the income distribution, is associated with higher support for competition, whereas being relatively poor, i.e. belonging to the lower $20 \%$ of the income distribution, is related to lower levels of support for competition (as compared to having a middle income). When looking at support for redistribution and reciprocity, however, this picture reverses: support for both redistribution and reciprocity is stronger among the relatively poor and weaker among the relatively affluent (though this latter difference does not gain significance for reciprocity). These findings are in line with our expectation formulated in Section 3 that social groups will differ in their support for market competition, redistribution and reciprocity since they vary in the degree to which they benefit from the market, the welfare state and the family. Along these lines, we also find that respondents with higher levels of education show stronger support for competition and less support for redistribution. Furthermore, people with secondary education report a statistically significant lower support for generalized reciprocity than lower educated respondents. The effect for citizens with tertiary education, however, remains insignificant. Finally, as expected, unemployed respondents are less supportive of competition but more supportive of redistribution, while the effect of unemployment on support for reciprocity is not statistically significant. In sum, these findings show that moral economies are contested and that support depends on being a beneficiary or being disadvantaged by specific institutional arrangements.

Looking at the control variables, we find that women are significantly less supportive of market competition than men. At the same time, they seem to favor redistribution policies more than men. Surprisingly, female respondents show lower support for reciprocal forms of economic integration than men do, possibly because housework and exchange within family networks is still mostly shouldered by women (Höpflinger and Fux, 2007). The age of respondents has a marginally significant positive effect on support for competition, while it does not significantly affect the preference for redistribution. For reciprocity we observe a curvilinear age effect, where support first declines and increases again at an older age. This finding might reflect the higher interest in both public and private care arrangements when getting older, while younger people might disapprove because they are not willing to onesidedly bear the cost of personal care for the old.

Furthermore, we also expected in Section 3 that the institutional manifestations of the three modes of economic integration might moderate the support rooted in respondents' social position. Thus, we assumed that differences between privileged and disadvantaged groups will be greater when market-embedding principles-which benefit the disadvantaged and demand greater contributions from the privileged-are more firmly institutionalized. Specifically, we expect high income-earners to demand more competition when markets are more strongly regulated, while support for redistribution and reciprocity among highincome earners should decrease when these principles are strongly institutionalized. In contrast, disadvantaged groups' support for competition should be lower in less regulated 
Table 3. Multi-level regression results

\begin{tabular}{|c|c|c|c|}
\hline Variable & $\begin{array}{c}\text { Model } 22 \\
\text { Competition }\end{array}$ & $\begin{array}{c}\text { Model } 23 \\
\text { Redistribution }\end{array}$ & $\begin{array}{c}\text { Model } 24 \\
\text { Reciprocity }\end{array}$ \\
\hline \multicolumn{4}{|l|}{ Individual effects } \\
\hline Constant & $3.504 * * *$ & $3.870 * * *$ & $4.415 * * *$ \\
\hline Female, Ref.: male & $-0.132 * * *$ & $0.176 * *$ & $-0.121 * * *$ \\
\hline Age & $0.003 * * *$ & 0.001 & $0.027 * * *$ \\
\hline $\mathrm{Age}^{2}$ & & & $0.000 * * *$ \\
\hline \multicolumn{4}{|c|}{ Education level, Ref.: primary education } \\
\hline Secondary education & $0.099 * * *$ & $-0.184 * * *$ & $-0.084 * * *$ \\
\hline Tertiary education & $0.147 * * *$ & $-0.403 * *$ & $0.056 * *$ \\
\hline \multicolumn{4}{|c|}{ HH Income, Ref.: middle income } \\
\hline Relative poverty & $-0.0704 * *$ & $0.139 * * *$ & $0.0946 * * *$ \\
\hline Relative affluence & $0.107 * * *$ & $-0.329 * * *$ & -0.011 \\
\hline missing value & $-0.064 *$ & $-0.138 * * *$ & $0.059 *$ \\
\hline Unemployed & $-0.203 * * *$ & $0.190 * * *$ & -0.014 \\
\hline \multicolumn{4}{|l|}{ Contextual effects } \\
\hline Market regulation & 0.060 & & \\
\hline \multicolumn{4}{|c|}{ Market reg. ${ }^{*} \mathrm{HH}$ income, Ref. mid } \\
\hline Market reg.* rel. poverty & 0.016 & & \\
\hline Market reg. *rel. affluence & -0.011 & & \\
\hline Market reg. "missing value & $-0.095 *$ & & \\
\hline Inequal. Red. & & $0.0204 * * *$ & \\
\hline \multicolumn{4}{|l|}{ Inequal. Red. ${ }^{*} \mathrm{HH}$ income } \\
\hline Inequal. Red. *rel. poverty & & $-0.008 * *$ & \\
\hline Inequal. Red. *rel. affluence & & $-0.012 * * *$ & \\
\hline Inequal. Red. *missing value & & $-0.005^{+}$ & \\
\hline Long term care (LTC) & & & $-0.505 *$ \\
\hline \multicolumn{4}{|l|}{ LTC*HH income } \\
\hline LTC*rel. poverty & & & 0.0471 \\
\hline LTC*rel. affluence & & & -0.007 \\
\hline LTC*missing value & & & $0.105 \%$ \\
\hline Variance Random Intercept & 0.044 & 0.076 & 0.092 \\
\hline ICC & $3.3 \%$ & $5.8 \%$ & $8.2 \%$ \\
\hline $\mathrm{N}$ & 20289 & 16699 & 16602 \\
\hline $\mathrm{BIC}$ & 62965.5 & 51094.5 & 47905.7 \\
\hline Log-Likelihood & -31408.4 & -25469.4 & -23880.0 \\
\hline
\end{tabular}

Note: Unstandardized regression coefficients; significance levels:

$* * P>0.001, * * P>0.01, * P>0.05,{ }^{+} P>0.10$.

Sources: WVS 99/00, ISSP 99, ISSP 2001, own calculations. Fourteen countries.

economies, and support for redistribution and reciprocity should be higher where the generosity of welfare states is higher, and/or where the family assumes a greater role. To test the relationship between individual and contextual characteristics, we estimated cross-level interactions (Table 3). We do not find a meaningful statistically significant cross-level interaction between market regulation and income regarding support for market competition. However, the different income groups' support for redistribution is significantly affected by 


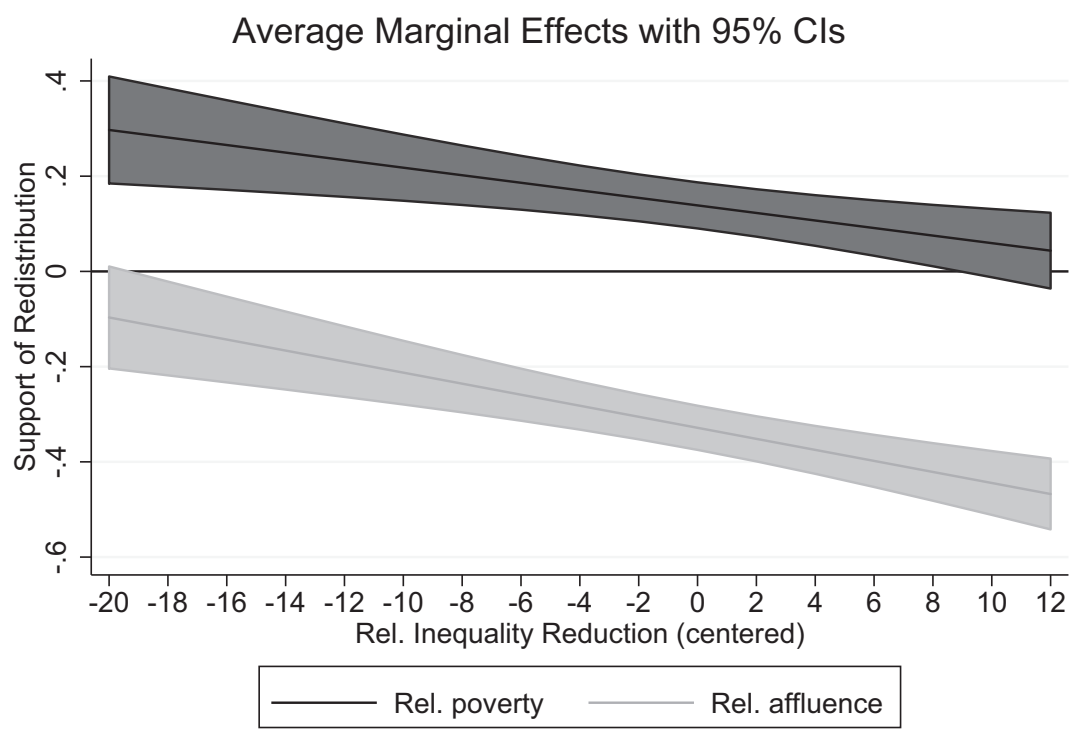

Figure 3. Average marginal effects of cross-level-interaction between inequality reduction and income groups (Ref. middle income).

the reduction of social inequality. Figure 3 plots the average marginal effects of being relatively poor and being relatively affluent on support for redistribution across the range of inequality reduction (having a middle income is the reference category). As predicted, with increasing public redistribution high-income earners become more averse to redistribution (in comparison to the middle income groups). Yet, somewhat counterintuitively, there also appears to be a slight decrease in redistributive preferences among the low-income group as redistribution increases. Further analyses (cf. Figure A7 in the Supplementary Appendix) show that this is mainly due to an increase in redistributive preferences among the middle class in high-redistribution countries. This is in line with Korpi and Palme's (1998) 'paradox of redistribution'-argument, which posits that encompassing welfare states foster coalitions between the poor and the middle class, while residual welfare states separate the poor from the rest. Our findings also indicate such shifting coalitions in support for redistribution as the degree of inequality reduction changes: In residual welfare states (e.g. New Zealand), the poor are confronted with low levels of support for redistribution among the middle and high income groups. In contrast, in highly redistributive contexts (e.g. Norway) the middle income group sides with the poor, showing relatively high support for redistribution as opposed to low support among the affluent.

For reciprocity, we do not find any moderation effect of the institutional context on the coefficients of the income groups. Using the alternative institutional measures to compute the cross-level interactions leads to similar results.

In sum, the results of the multivariate analyses suggest that in line with our Polanyian expectations, citizens' normative support for only one of the three principles of economic integration is grounded in corresponding institutions of the political economy: while the support of market competition is independent of the level of regulation, support for redistribution strongly corresponds to the institutional arrangements of the welfare state. The level of support for reciprocity remains puzzling. While we observe large variations across countries, our (limited) institutional measures did provide mixed support for an institutional 
foundation of reciprocity. Yet, economic development seems to be more important in explaining support for reciprocity than specific institutional conditions, probably because it crowds out reciprocal types of economic integration, resembling classical arguments on the declining importance of reciprocity in modern societies (Luhmann, 2012).

\section{Conclusion}

The point of departure for our investigation was the notion that in the institutional architecture of contemporary capitalist societies, markets are not the only form of economic integration but that they are supplanted by and embedded in alternative modes of economic integration, specifically redistribution and reciprocity (Polanyi, 1992 [1957]; Swedberg, 2003 , p. 28). From a 'moral economy' perspective, we have examined whether there is a correspondence between formal institutional arrangements and citizens' normative orientations. While previous research provides ample evidence of the link between welfare state institutions and popular attitudes towards redistribution (Mau, 2003; Svallfors, 2006; Schmidt-Catran, 2016), considerably less attention has been paid to popular views of markets and (family) reciprocity, as well as their relation to formal institutions. Thus, we have asked whether popular support for Polanyi's three forms of economic integration-market competition, redistribution and reciprocity-differs across a range of economically, politically and institutionally diverse set of countries. Furthermore, we have specifically analyzed potential interrelations between the three attitudinal domains and identified systematic patterns of popular support that cluster into three distinct 'varieties of moral economies'.

Keeping in mind the limitations of our operationalization of market competition and reciprocity, our findings suggest that market ideology is not disembedded but instead is-to different degrees-contained by other normative principles, which are reflected in citizens' normative orientations. The descriptive results show that a strong support of market competition as a form of economic integration exists. Yet, support for competition is often supplemented by a demand for redistribution and reciprocity, resulting in varieties of 'moral economies'. We identify three distinct moral economies that differ systematically in the importance they attribute to either mode of economic integration. In the 'competition-dominated moral economies' made up of Anglo-Saxon nations (USA, Canada, Australia, New Zealand, Great Britain) and Japan, support for market competition is strong, while support for redistribution and reciprocity is relatively weak. In the 'embedded moral economies' of Norway, Germany, Austria and the Czech Republic, support for competition is equally strong, but it is complemented by comparatively high levels of support for redistribution and reciprocity. In the 'strongly embedded moral economies' comprising Poland, Hungary, Spain and France, support for redistribution and reciprocity is stronger still, while support for market competition is considerably weaker. These results support the findings of Levien and Paret (2012), who, for a somewhat different set of countries, find strong proembeddedness sentiments not only in the former communist countries, but also in Spain and Germany during the nineties.

Furthermore, we expected support for market competition, redistribution and reciprocity to be anchored in a set of historically grown corresponding formal institutions, i.e. market regulation, state-administered reduction of social inequality and long-term care arrangements, respectively. When we solely include the institutional indicator corresponding to a specific normative principle in the multivariate models, we find a statistically significant 
relation between inequality reduction and support for redistribution, as well as public expenditure for long-term care and reciprocity, while support for competition is not significantly associated with market regulation. Controlling for the level of economic development and using alternative institutional measures confirm, that support of market competition is not related to market regulating institutions, while support for redistribution is significantly associated with various measures of the welfare state. However, we also observe that the relationship between the institutional foundation of reciprocity and its normative support is not statistically robust. Instead, increasing economic prosperity appears to crowd out support for reciprocity.

Finally, support for all three modes of economic integration is contested between economically privileged and disadvantaged social groups. Affluent groups are more approving of market competition, while at the same time disapproving of redistribution and reciprocity. In contrast, disadvantaged groups are less supportive of competition and more supportive of market-embedding principles, i.e. redistribution and reciprocity. Notably, redistributive policies moderate the difference in support for redistribution between these groups. Congruent with Korpi and Palme's (1998) 'paradox of redistribution'-argumentwhich expects redistributive coalitions between the poor and the middle-class to emerge in encompassing welfare states-we find that stronger state-administered reduction of inequality increases support for redistribution specifically among low- and middle-income groups. In contrast, privileged groups are more disapproving of redistribution when they live in a country with extensive redistributive policies than when living in a country with low levels of public redistribution. More generally, this suggests that opposition to market-embedding normative principles among the relatively affluent is higher in contexts that institutionalize these principles-here: redistribution-to a greater extent. Future research should investigate this from a longitudinal perspective to see whether changes in redistribution also lead to changes in the redistributive attitudes of the affluent, possibly indicating the beginnings of a Polanyian 'double movement'. Furthermore, in order to see whether there is indeed no association between market-embedding institutions and attitudes towards market principles or family reciprocity, respectively, better attitudinal measures in future comparative surveys and the development of alternative measures of family reciprocity would be valuable.

In sum, our findings point to the normative support for alternative modes of economic integration besides the market. On the aggregate level, support for competition, redistribution and reciprocity varies systematically across countries, forming three distinct clusters of moral economies. Support for the principle of redistribution is conditional on the presence of a set of corresponding institutions, whereas support for market competition and reciprocity cannot be easily explained by institutional conditions. Furthermore, these principles are endorsed to varying degrees by different social groups, highlighting the fact that moral economies are not uncontested. Congruent with our argumentation, then, the results show that besides differences in their formal institutional architecture, capitalist democracies also differ with regard to their 'ideational embeddedness' (Somers and Block, 2005, p. 263). Max Weber once expected that a fully developed capitalist economy would eventually come to rest solely on a 'mechanical foundation' (Weber, 2002, p. 124) and no longer require a non-economic legitimation, and we indeed find that support for competition is detached from market regulating institutions. Yet, our analysis also suggests that not everywhere 'the pursuit of gain [...] tends to be associated with purely competitive passions', thereby instilling 'the character of a sporting contest' (Weber, 2002, p. 124) into the economic sphere. 
Rather, varying configurations of support for the three modes of integration identified by Polanyi combine into distinct 'moral economies' of market societies. In some societies, market competition is contained by strong preferences for redistribution and/or reciprocity. While the latter seems to be prevalent in economically less developed countries, the former is based on and sustained by historically entrenched and socially contested institutions and policies of redistribution, which embed market principles to some degree. As our analysis rests on cross-sectional data, we cannot say how these distinct moral economies will evolve in the face of ongoing tendencies towards further economization and marketization of the institutional architecture of contemporary capitalism (but see: Levien and Paret, 2012). Yet, studying not only the institutional but also the 'ideational' trajectories of capitalist variety appears to us as a promising avenue for future research.

\section{Acknowledgements}

Author listing is alphabetical; both authors contributed equally to this article. Prior versions of this paper have been presented at the conference of the German Sociological Association at Ruhr University Bochum in 2012, in talks at Goethe University Frankfurt, Germany, in 2013 and at Lund University, Sweden, in 2016. We would like to thank the participants on these occasions for their valuable input und comments. Additionally, we are grateful to Bruno Amable, Gregory Jackson, Elias Naumann and four anonymous reviewers for helpful suggestions and criticism.

\section{References}

Adloff, F. and Mau, S. (2006) 'Giving Social Ties - Reciprocity in Modern Societies', European Journal of Sociology, 47, 93-123.

Albertini, M. and Kohli, M. (2013) 'The Generational Contract in the Family: An Analysis of Transfer Regimes in Europe', European Sociological Review, 29, 828-840.

Almond, G. A. and Verba, S. (1989) The Civic Culture. Political Attitutdes and Democracy in Five Nations, Boston, Little, Brown and Company.

Amable, B. (2003) The Diversity of Modern Capitalism, Oxford, Oxford University Press.

Aspers, P. (2009) Markets, Cambridge, Polity Press.

Barr, N. (2001) The Welfare State as Piggy Bank. Information, Risk, Uncertainty, and the Role of the State, Oxford, Oxford University Press.

Beckert, J. (2007) Inherited Wealth, Princeton, Princeton University Press.

Beckert, J. (2009) 'The Social Order of Markets', Theory and Society, 38, 245-269.

Beckert, J. (2012) 'Die Sittliche Einbettung Der Wirtschaft', Berliner Journal für Soziologie, 22, 247-266.

Block, F. (2001) 'Introduction'. In Polanyi, K. (ed.) The Great Transformation. The Political and Economic Origins of Our Time, Boston, Beacon Press, pp. xviii-xxxviii.

Block, F. and Somers, M. R. (2014) The Power of Market Fundamentalism, Cambridge, MA, Harvard University Press.

Bolzendahl, C. and Myers, D. J. (2004). 'Feminist Attitudes and Support for Gender Equality: Opinion Change in Women and Men, 1974-1998'. Social Forces, 83, 759-790. 
Bradley, D., Huber, E., Moller, S., Nielsen, F. and Stephens, J. D. (2003) 'Distribution and Redistribution in Postindustrial Democracies', World Politics, 55, 193-228.

Brandt, M., Haberkern, K. and Szydlik, M. (2009) 'Intergenerational Help and Care in Europe', European Sociological Review, 25, 585-601.

Bryan, M. L. and Jenkins, S. P. (2016) 'Multilevel Modelling of Country Effects: A Cautionary Tale', European Sociological Review, 32, 3-22.

Cook, L. J. (2010) 'Eastern Europe and Russia'. In Castles, F. G., Leibfried, S., Lewis, J., Obinger, H. and Pierson, C. (eds) Oxford Handbook of the Welfare State, Oxford, Oxford University Press, pp. 671-688.

Crouch, C. (2009) 'Marketization'. In Flinders, M., Gamble, A., Hay, C. and Kenny, M. (eds) The Oxford Handbook of British Politics, Oxford, Oxford University Press, pp. 879-895.

Dale, G. (2010) Karl Polanyi: The Limits of the Market, Cambridge, Polity Press.

Daly, M. (2010) 'Families Versus State and Market'. In Castles, F. G., Leibfried, S., Lewis, J., Obinger, H. and Pierson, C. (eds) The Oxford Handbook of the Welfare State, Oxford, Oxford University Press, pp. 140-151.

Djelic, M.-L. (2006) 'Marketization: From Intellectual Agenda to Global Policy-Making'. In Djelic, M.-L. and Sahlin-Andersson, K. (eds) Transnational Governance. Institutional Dynamics of Globalization, Cambridge, Cambridge University Press, pp. 53-73.

Duda, R. O. and Hart, P. E. (1973) Pattern Classification and Scene Analysis, New York, Wiley.

Durkheim, E. (1893) De La Division Du Travail Social, Paris, Puf 1930.

Esping-Andersen, G. (1990) The Three Worlds of Welfare Capitalism, London, Polity Press.

Esping-Andersen, G. (1999) Social Foundations of Postindustrial Economies, Oxford, Oxford University Press.

Everitt, B. S., Landau, S., Leese, M. and Stahl, D. (2011) Cluster Analysis, Chichester, Wiley.

Fehr, E. and Schmidt, K. M. (2006) 'The Economics of Fairness, Reciprocity and Altruism-Experimental Evidence and New Theories', Handbook of the Economics of Giving, Altruism and Reciprocity, 1, 615-691.

Flora, P., Alber, J. and Kohl, J. (1977) 'Zur Entwicklung Der Westeuropäischen Wohlfahrtsstaaten', Politische Vierteljahresschrift, 18, 705-772.

Fourcade, M. and Healy, K. (2007) 'Moral Views of Market Society', Annual Review of Sociology,.., 33, 285-311.

Gingrich, J. (2011) Making Markets in the Welfare State: The Politics of Market Variation, Cambridge, Cambridge University Press.

Guo, G. and Zhao, H. (2000) 'Multilevel Modeling for Binary Data', Annual Review of Sociology, 26, 441-462.

Gwartney, J., Lawson, R. and Hall, J. (2011) Economic Freedom of the World: 2011 Annual Report, Fraser Institute, accessed at www.fraserinstitute.org on June 23, 2017.

Hall, P. and Soskice, D. (eds) (2001) Varieties of Capitalism. The Institutional Foundations of Comparative Advantage, Oxford, Oxford University Press.

Hall, P. A. and Gingerich, D. W. (2004) 'Varieties of Capitalism and Institutional Complementarities in the Political Economy: An Empirical Analysis', MPIfG Discussion Paper 04.

Heinze, R. G. (2010) Rückkehr Des Staates? Politische Handlungsmöglichkeiten in Unsicheren Zeiten, Wiesbaden, VS.

Hildreth, A. K. G. and Oswald, A. J. (1997) 'Rent-Sharing and Wages: Evidence from Company and Establishment Panels', Journal of Labor Economics 15, 318-337.

Hollingsworth, J. R., Schmitter, P. C. and Streeck, W. (1994) Governing Capitalist Economies: Performance and Control of Economic Sectors, Oxford, Oxford University Press.

Höpflinger, F. and Fux, B. (2007) 'Familien- Intereuropäische Perspektive'. In Ecarius, J. (ed.) Handbuch Familie, Wiesbaden, VS. 
Huber, E. and Stephens, J. D. (2005) 'Welfare States and the Economy'. In Swedberg, R. (ed.) Handbook of Economic Sociology. Second Edition, Princeton, Princeton University Press, pp. 552-574.

Kenworthy, L. and Pontusson, J. (2005) 'Rising Inequality and the Politics of Redistribution in Affluent Countries. Perspectives on Politics, 3, 449-471.

Kluegel, J. R. and Smith, E. (1986) Beliefs about Inequality. American's View of What is and What ought to be. New York, Aldine de Gruyter.

Kluegel, J. R., Mason, D. S. and Wegener, B. (1999) 'The Legitimacy of Capitalism in the Postcommunist Transition Public Opinion About Market Justice, 1991-1996', European Sociological Review, 15, 251-283.

Knell, M. and Srholec, M. (2007) 'Diverging Pathways in Central and Eastern Europe'. In Lane, D. and Myant, M. (eds) Varieties of Capitalism in Post-Communist Countries, Houndmills, Palgrave Macmillan, pp. 40-62.

Koos, S. (2012) 'The Institutional Embeddedness of Social Responsibility: A Multilevel Analysis of Smaller Firms' Civic Engagement in Western Europe', Socio-Economic Review, 10, 135-162.

Korpi, W. and Palme, J. (1998) 'The Paradox of Redistribution and Strategies of Equality: Welfare State Institutions, Inequality, and Poverty in the Western Countries', American Sociological Review, 63, 661-687.

Kuitto, K. (2016) Post-Communist Welfare States in European Context: Patterns of Welfare Policies in Central and Eastern Europe, Cheltenham, Edward Elgar Publishing.

Kwon, R. (2016) 'Can We Have Our Cake and Eat It Too? Liberalization, Economic Growth, and Income Inequality in Advanced Industrial Societies’, Social Forces, 95, 469-502.

Leitner, S. (2003) 'Varieties of Familialism: The Caring Function of the Family in Comparative Perspective', European Societies, 5, 353-375.

Lepsius, R. M. (1995) 'Institutionenanalyse Und Institutionenpolitik'. In Nedelmann, B. (ed.) Politische Institutionen Im Wandel, Sonderheft 35 Der Kölner Zeitschrift Für Soziologie Und Sozialpsychologie, Opladen, Westdeutscher, pp. 392-403.

Levien, M. and Paret, M. (2012) 'A Second Double Movement? Polanyi and Shifting Global Opinions on Neoliberalism', International Sociology, 27, 724-744

Lindh, A. (2014) Attitudes Towards the Market and the Welfare State. Dissertation, Umeå, Umeå University.

Lindh, A. (2015) 'Public Opinion against Markets? Attitudes Towards Market Distribution of Social Services - a Comparison of 17 Countries', Social Policy \& Administration, 49, 887-910.

Lipset, S. M. (1996) American Exceptionalism. A Double-Edged Sword. New York, W. W. Norton \& Company.

Luhmann, N. (2012) Theory of Society, Volume 1, Stanford, Stanford University Press.

Marshall, T. H. (1950) Citizenship and Social Class and Other Essays, Cambridge, Cambridge University Press.

Mason, D. S. (1995) 'Justice, Socialism, and Participation in the Postcommunist States'. In Mason, D. S., Kluegel, J. R. and Wegener, B. (eds) Social Justice and Political Change, Berlin, Walter de Gruyter, pp. 49-80.

Mason, D. S. and Kluegel, J. R. (eds) (2000) Marketing Democracy. Changing Opinion About Inequality and Politics in East Central Europe, Lanham, Rowman \& Littlefield.

Mau, S. (2003) The Moral Economy of Welfare States: Britain and Germany Compared, London, Routledge.

Mau, S. (2005) 'Moral Economy'. In Beckert, J. and Zafirovski, M. (eds) International Encyclopedia of Economic Sociology, London, Routledge, pp. 466-469.

Morel, N.; Palier, B.; Palme, J. (2012) Towards a Social Investment Welfare State?: Ideas, Policies and Challenges, Bristol, Policy Press. 
Newman, K. S. (2012) The Accordion Family: Boomerang Kids, Anxious Parents, and the Private Toll of Global Competition, Boston, Beacon Press.

North, D. C. (1990) Institutions, Institutional Change and Economic Performance, Cambridge, Cambridge University Press.

OECD (2005) Long-Term Care for Older People, Paris, OECD Publishing.

OECD (2009) OECD Indicators on Employment Protection - Update 2009, Paris, OECD.

OECD (2012) Social Expenditure Database, accessed at www.oecd.org/els/social/expenditure on June 23, 2017.

OECD (2014) OECD Family Database, Paris, accessed at www.oecd.org/els/social/family/data base on June 23, 2017.

Palier, B. (2010) 'Continental Western Europe'. In Castles, F. G., Leibfried, S., Lewis, J., Obinger, H. and Pierson, C. (eds) Oxford Handbook of the Welfare State, Oxford, Oxford University Press.

Palme, J. (2006) 'Welfare States and Inequality: Institutional Designs and Distributive Outcome', Research in Social Stratification and Mobility, 24, 387-403.

Polanyi, K. (1957 [1944]) The Great Transformation. The Political and Economic Origins of Our Time, Boston, Beacon.

Polanyi, K. (1992 [1957]) 'The Economy as Instituted Process'. In Granovetter, M. and Swedberg, R. (eds) The Sociology of Economic Life, Boulder, Westview Press, pp. 29-51.

Poortman, A. R. and Van der Lippe, T. (2009) 'Attitudes Toward Housework and Child Care and the Gendered Division of Labor. Journal of Marriage and Family, 71, 526-541.

Rotemberg, J. J. (2006) 'Altruism, Reciprocity and Cooperation in the Workplace'. In Kolm, S.-C. and Mercier, Y.-J. (eds) Handbook of the Economics of Giving, Altruism and Reciprocity, Volume 2, Amsterdam, Elsevier, pp. 1372-1407.

Rothstein, B. (1998) Just Institutions Matter. The Moral and Political Logic of the Universal Welfare State, Cambridge, Cambridge University Press.

Sachweh, P. (2012) 'The Moral Economy of Inequality: Popular Views on Income Differentiation, Poverty, and Wealth', Socio-Economic Review, 10, 419-445.

Sahlins, M. D. (1972) Stone Age Economics, New Brunswick, NJ, Transaction Publishers.

Sayer, A. (2007) 'Moral Economy as Critique', New Political Economy, 12, 261-270.

Schmidt-Catran, A. W. (2016) 'Economic Inequality and Public Demand for Redistribution: Combining Cross-Sectional and Longitudinal Evidence', Socio-Economic Review, 14, 119-140.

Schneider, M. R. and Paunescu, M. (2012) 'Changing Varieties of Capitalism and Revealed Comparative Advantages from 1990 to 2005: a Test of the Hall and Soskice Claims', Socio-Economic Review, 10, 731-753.

Scruggs, L., Jahn, D. and Kuitto, K. (2014) Comparative Welfare Entitlements Dataset 2. Version 2014-03., University of Connecticut \& University of Greifswald.

Slater, D. and Tonkiss, F. (2001) Market Society. Markets and Modern Social Theory, Cambridge, Polity Press.

Snijders, T. A. B. and Bosker, R. J. (1999) Multilevel Analysis, London, Sage.

Solt, F. (2016) 'The Standardized World Income Inequality Database', Social Science Quarterly, 97, 1267-1281.

Somers, M. R. and Block, F. (2005) 'From Poverty to Perversity: Ideas, Markets, and Institutions over 200 Years of Welfare Debate', American Sociological Review, 70, 260-287.

Streeck, W. (2010) 'Does "Behavioural Economics" Offer an Alternative to the Neoclassical Paradigm?', Socio-Economic Review, 8, 387-397.

Streeck, W. and Schmitter, P. C. (1985) 'Community, Market, State-and Associations? The Prospective Contribution of Interest Governance to Social Order', European Sociological Review, 1, 119-138. 
Streeck, W. and Thelen, K. A. (2005) 'Institutional Change in Advanced Political Economies'. In Streeck, W. and Thelen, K. A. (eds) Beyond Continuity: Institutional Change in Advanced Political Economies, Oxford, Oxford University Press, pp. 1-39.

Suchman, M. C. (1995) 'Managing Legitimacy: Strategic and Institutional Approaches', Academy of Management Review, 20, 571-610.

Svallfors, S. (2006) The Moral Economy of Class. Class and Attitudes in Comparative Perspective, Stanford, Stanford University Press.

Svallfors, S. (2010) 'Public Attitudes'. In Castles, F. G., Leibfried, S., Lewis, J., Obinger, H. and Pierson, C. (eds) The Oxford Handbook of the Welfare State, New York, Oxford University Press, pp. 241-251.

Swedberg, R. (2003) Principles of Economic Sociology, Princeton, Princeton University Press.

Szelényi, I. and Kostello, E. (1992) 'Outline of an Insitutionalist Theory of Inequality: The Case of Socialist and Postcommunist Eastern Europe'. In Brinton, M. C. and Nee, V. (eds) The New Institutionalism in Sociology, New York, Russel Sage Foundation, pp. 305-326.

Szydlik, M. (2011) 'Erben in Europa', Kölner Zeitschrift für Soziologie und Sozialpsychologie, 63, 543-565.

Thompson, E. P. (1971) 'The Moral Economy of the English Crowd in the Eighteenth Century', Past and Present, 50, 76-136.

van Oorschot, W., Opielka, M. and Pfau-Effinger, B. (2008) 'The Culture of the Welfare State: Historical and Theoretical Arguments'. In van Oorschot, W., Opielka, M. and Pfau-Effinger, B. (eds) Culture and Welfare State: Values and Social Policy in Comparative Perspective., London, Edward Elgar, pp. 1-26.

Vrooman, J. C. (2012) 'Regimes and Cultures of Social Security: Comparing Institutional Models through Nonlinear Pca', International Journal of Comparative Sociology, 53, 444-477.

Weber, M. (1980 [1922]) Wirtschaft Und Gesellschaft. Grundriss Der Verstehenden Soziologie, Tübingen, Mohr.

Weber, M. (2002) The Protestant Ethic and the Spirit of Modern Capitalism, 3rd, Los Angeles, Roxbury.

Whitley, R. (1999) Divergent Capitalisms: The Social Structuring and Change of Business Systems: The Social Structuring and Change of Business Systems, Oxford, Oxford University Press.

Wilensky, H. (1975) The Welfare State and Equality. Structural and Ideological Roots of Public Expenditures, Berkeley, University of California Press.

Williamson, O. E. (1981) 'The Economics of Organization: The Transaction Cost Approach', The American Journal of Sociology, 87, 548-577.

Witt, M. A. and Jackson, G. (2016) 'Varieties of Capitalism and Institutional Comparative Advantage: A Test and Reinterpretation', Journal of International Business Studies, 47, 778-806.

Worldbank (2012) World Bank World Development Indicators, accessed at www.worldbank. org/ on June 23, 2017. 